\title{
Preservation of Indonesian Culture through Traditional Games Application
}

\author{
Elsa Regiana $^{1}$, Albertus Dwiyoga Widiantoro ${ }^{2}$, FX. Hendra Prasetya ${ }^{3}$ \\ 1,2,3 Department of Information Systems, Computer Science Faculty \\ Soegijapranata Catholic University, Semarang, Indonesia \\ 1'elsareg@gmail.com,2yoga@unika.ac.id, ${ }^{3}$ hendra@unika.ac.id
}

\begin{abstract}
In the face of technological developments that are more advanced, it takes action to preserve the culture. Preservation of Indonesian culture can be done through the media game. Although the game play still has a bad image in the eyes of the parents, but slowly this negative stigma may be reduced if the digital game can be packaged properly as an example as a means to educate children.

For that traditional game application titled Ensiklo Dolanan made with the concept of educational games by presenting information and games around the traditional games are packaged in an interesting way to increase the enthusiasm of children in the effort to preserve the traditional game.
\end{abstract}

Keyword: Traditional Game, Cultural Heritage, Educational Game

\section{INTRODUCTION}

Playing is a fun activity that has become an inherent need in children [1]. Prior to the existence of gadgets, playing not just silent and staring at the screen, but involving members of the body and also the process of social interaction through traditional games. Traditional gameplay is a fun activity process by using simple tools according to the circumstances that are the result of local cultural excavations according to the teachings of the ancestors [2]. These are the things that make traditional games have a positive impact on child development. To quote Ismatul Khasanah, et al, in addition to having a noble meaning, the game. Traditionally invites physical and emotional children to engage directly and can teach children to explore and experiment [3].

Nevertheless, many traditional games are being abandoned, based on traditional game observer community data, it is estimated that there are more than 1,000 types of traditional games both objects and objects, but only 20 percent of the games are still actively played [4].

To know the existence of traditional games in children's play activities today, the authors surveyed 30 children, with the first question "Have you ever played traditional games?" $55 \%$ of kids answered that they had played traditional games, $33 \%$ answered frequently and $12 \%$ answered never. Furthermore, the authors provide further questions to know the intensity of these children in playing traditional games with a period of one week. The result, $37 \%$ of children answered more than 3 times, $50 \%$ of children answered 1-2 times and 13\% of children answered never played at all. Based on this, it can be seen that children who answered never played traditional games mostly only play it 1-2 times a week. If added with children who never play it, then the conclusion is $63 \%$ or 26 children or most respondents not too often never even play traditional games, as seen in Figure 1 and Figure 2. 


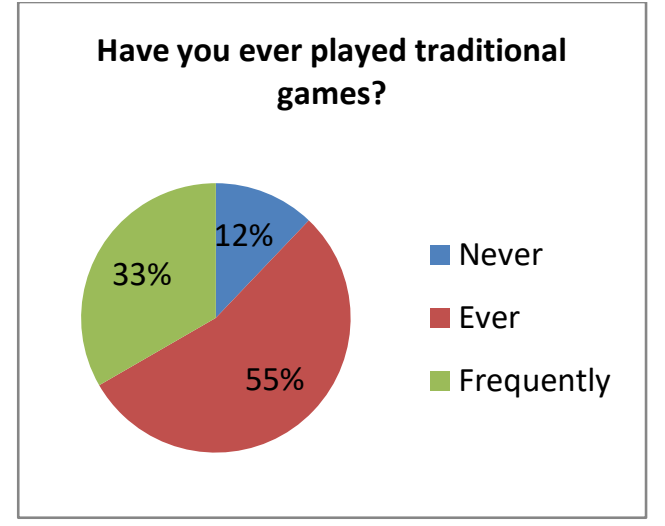

Fig. 1 Respondents' data never or did not play traditional games

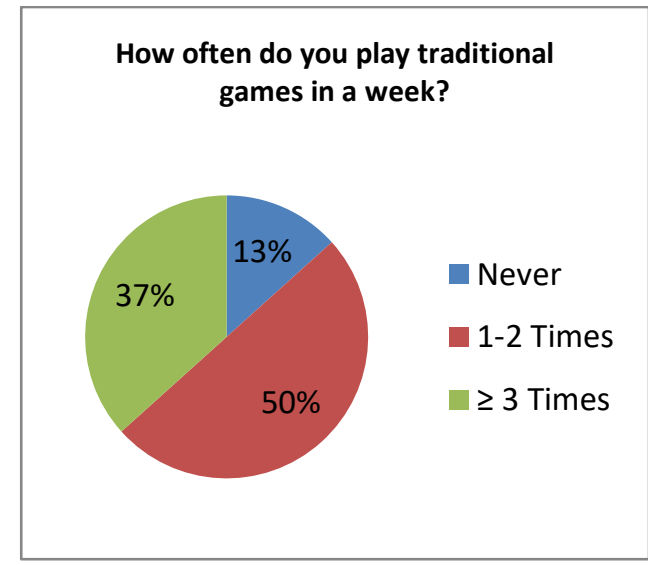

Fig. 2 The data of respondents to traditional game play habits

Many efforts have been made by various parties to preserve traditional games such as building museums and making community. In addition to the above efforts, there is nothing wrong if the preservation of traditional games is done by utilizing technological progress following the technology. In the context of culture, utilizing information technology in an effort to preserve the culture is called cultural digitization, this concept can be used by the creative industry in developing educational or gaming applications [5].

Digital games or video games are now more striking in the hearts of people because of the growing gadget culture is becoming more sophisticated. According to SuperData Unity reports a day a mobile game player uses his smartphone to play three sessions with an average playing time of 10 minutes per session [6]. This is also reinforced by the survey that the authors ask through the question "Do you play video games often?" Of this question $63 \%$ of children answered ever and $37 \%$ of children answered frequently and $0 \%$ answered never. Then given the question to find out how much time children play in one day, $73 \%$ of children answered play for 1-2 hours, $20 \%$ children answered 34 hours and $7 \%$ children answered more than 5 hours, as shown in figure 3 and figure 4 .

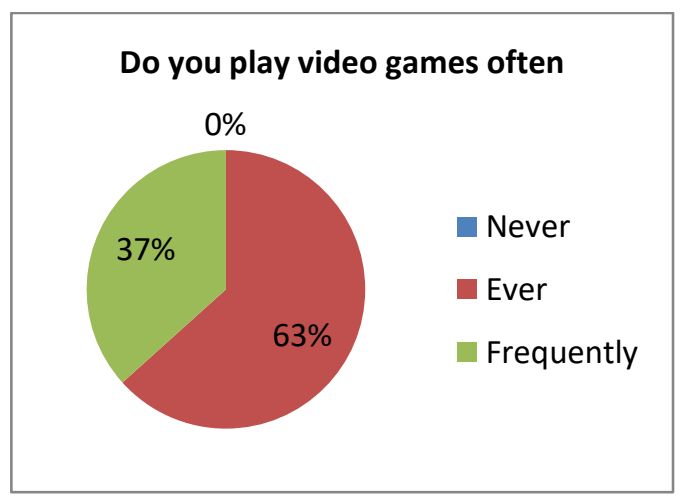

Fig. 3 Respondent data never or not playing games

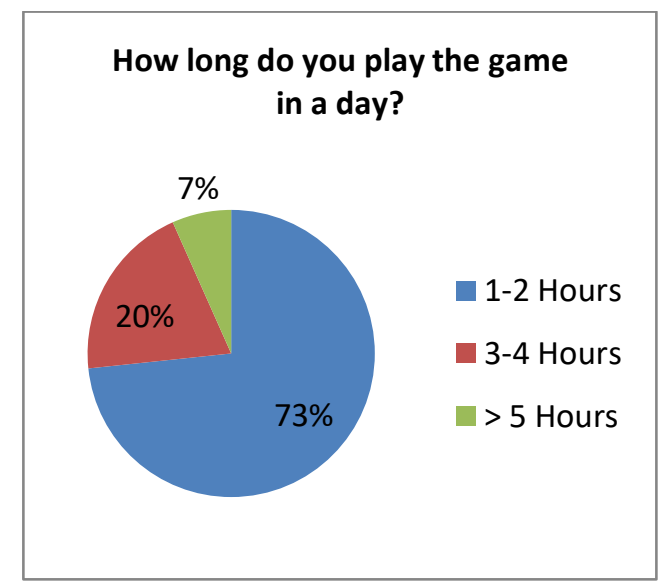

Fig. 4 Respondents' data on game play habits

By looking at the above case the authors take advantage of current technological advances by making Androidbased mobile games applications as a medium to introduce traditional games, because the game media is considered to make delivering information becomes easier and more interesting.

\section{LITERATURE REVIEW}

\section{A. Traditional Game}

Permainan (game) is a noun derived from the word 'main' (the verb). According to 
KKBI Online, 'main' means doing deeds for pleasure using either equipment or not. So the game is an object or thing used to play and get pleasure [7]. The traditional term comes from the word tradition; tradition means custom or habit that is still run by society for generations. While traditional has a meaning attitude or way of thinking and behaving that cling to the customs and norms that exist [8]. Then the traditional game is something that is done (played) according to hereditary customs to give pleasure.

\section{B. Cultural Preservation}

Preserving does not mean to make it unbearable and durable, but preserving is how we can work hand in hand to preserve the culture for a long time. Cultural preservation will not be realized without local strength, inner strength and self-help power of the observers, lovers and supporters and the whole society [9]. According Safril Mubah to face the challenges of globalization, a strategy is needed in an effort to increase Indonesia's cultural endurance [10], one is the use of technology, technology has a great opportunity to master civilization in this era. To utilize technological progress is a strategy that can be done to develop and preserve local cultural values into a product with high added value [10].

\section{Technology in Culture}

The use of information technology is a benefit expected by IT actors in the performance of their duties, measured by the frequency and intensity of utilization and the diversity of applications run [11]. The concept of the utilization of technology in the field of culture is known by the digitalization of culture, namely the use of information and communication technology in terms of documentation and dissemination of information from cultural elements to enhance the existence and preserve the culture of Indonesia, cultural elements such as arts, religious systems, science and knowledge, livelihood and economic systems, languages, systems of community organizations and systems of technology and equipment [10].

\section{Game}

Some notions of digital games are as follows [12]:

1. Game is an interactive program that allows one or more players to engage with content especially for entertainment purposes.

2. A popular form of entertainment and media use, which also offers the possibility to learn.

3. An electronic game in which the player controls the image on a television or computer screen.

\section{METHODOLOGY}

\section{A. Objects and Location Research}

The object of research this Traditional Game Application is children with an age range of $8-13$ years. Because this is the age in which children play with game tools and involve their social environment, as can be found in traditional games [13]. As for the selection of research sites conducted several places in the district of Semarang and Semarang City to see the knowledge and interest about traditional games from various regions.

\section{B. Data Source}

In the study of Traditional Game Games using two sources of data are as follows:

1. Primary data source, data obtained directly through the questionnaire. In this study the primary data source is the conclusion of the results of pre-test questionnaire and post-test and the results of observations to the respondents both before and after playing the game.

2. Secondary data sources, data obtained from existing data. In this case the authors use the data from previous research through journals or other 
writings that explain the importance of preserving the traditional game.

\section{Data Collection Techniques}

1. Literature / Library Studies

Library study is a technique of collecting data and relevant information and underlying research, derived from scientific books, journals, research reports and printed or electronic written sources [14]. The literature sources in this research are taken from journals and articles mainly related to traditional games, ranging from history, types of games, how to play and its benefits.

\section{Questionnaire}

The questionnaire is a method of collecting data by providing a set of questions or written statement to the respondent used to obtain information. Questionnaires were distributed prior to the creation and after the game creation to find out information as a basis for game creation and the impact of games that have been created and played.

\section{RESULTS AND DISCUSSION}

\section{A. Game Design}

Prior to the start of game creation, analysis and calculation of pre-test questionnaires were used to measure the extent to which children were familiar with traditional games and also to determine what traditional games would be included in the game. The survey was conducted on 30 children with age limit of 8 - 13 years with ratio of male and female ratio $53 \%$ and $47 \%$. Here are some data of pre-test result:

First, given the question to find out how interested the child with the traditional game and the result $73 \%$ expressed interest, $27 \%$ of children expressed great interest. As shown in the diagram in figure 5.

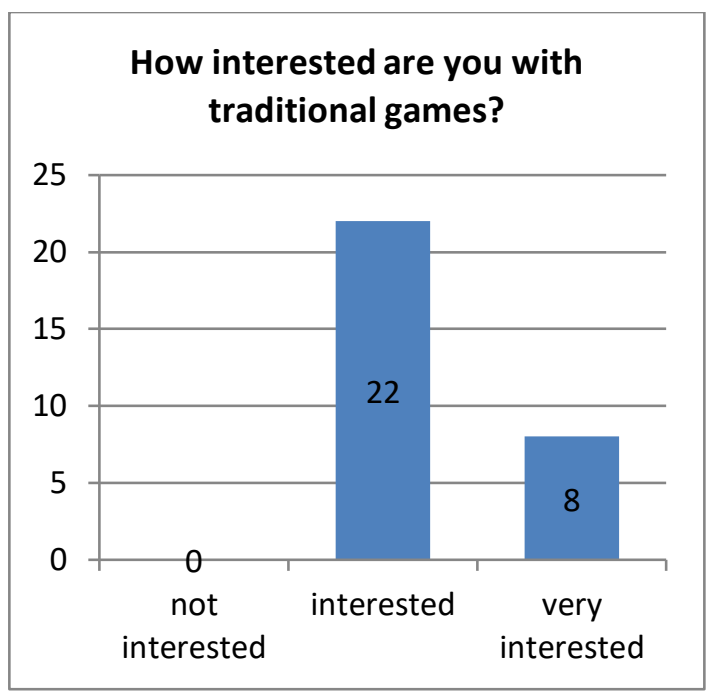

Fig. 5 Diagram of how often traditional games are played

Then to find out what traditional games that respondents have played given 8 traditional game names and the results as follows:

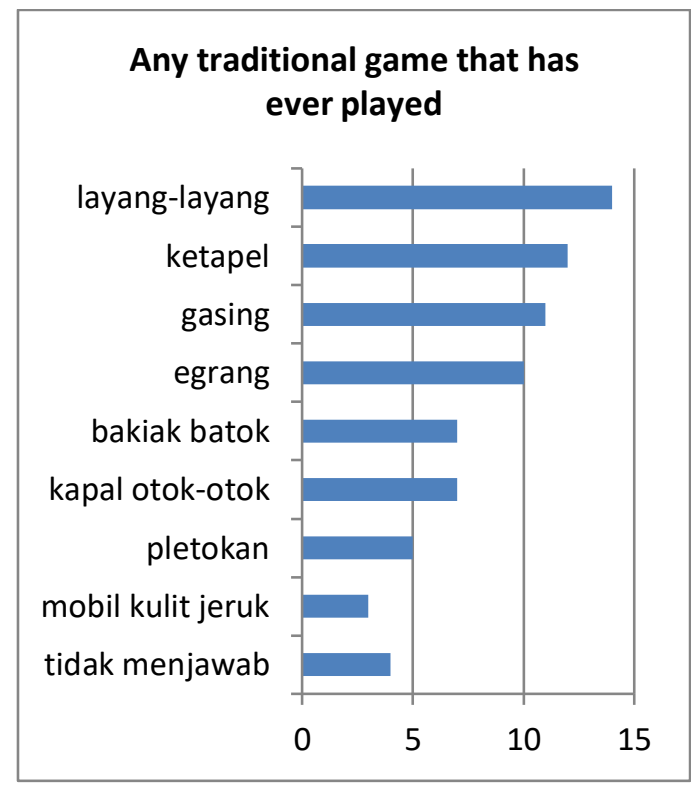

Fig. 6 Traditional Games Graphics are often played

From the data in Figure 6 can be known which traditional games are popular among respondents. Layang-layang became the most played game by the respondents which amounted to 14 children, while the bakiak batok 7 children, pletokan 5 children, gasing 11 children, kapal otok-otok 7 children, ketapel 12 children, egrang 10 children, 
and mobil kulit jeruk became a game that is rarely played because it is only selected by 3 children.

Furthermore, to find out if the children know the information and history of traditional games then given the question with the results as in figure 7.

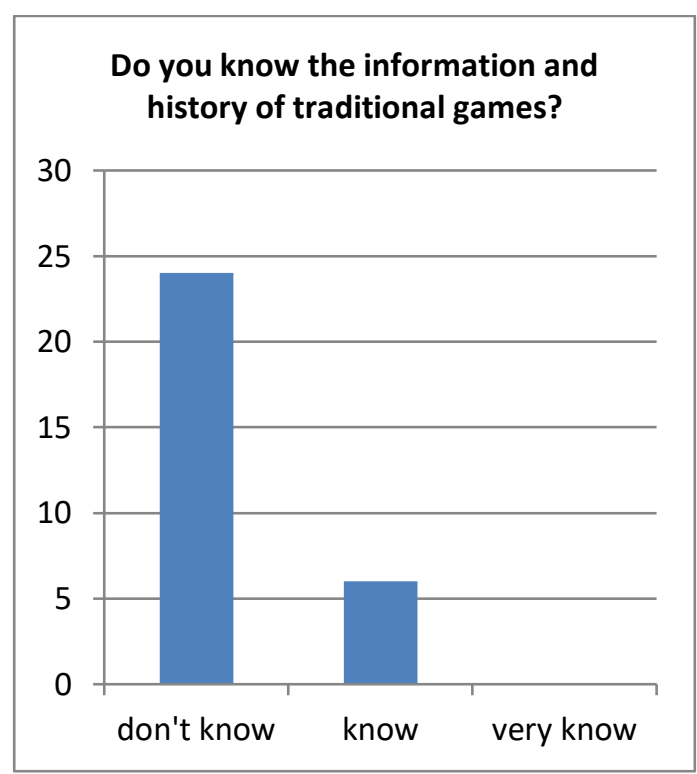

Fig. 7 Respondents' knowledge diagram of traditional game information

Based on the above diagram analysis, $80 \%$ of respondents or 22 children said they do not know about the information and history of the game and the rest is 8 children say know.

After considering the pre-test results gameplay and gameplay draft game in a diagram or flowchart to facilitate the process of programming.

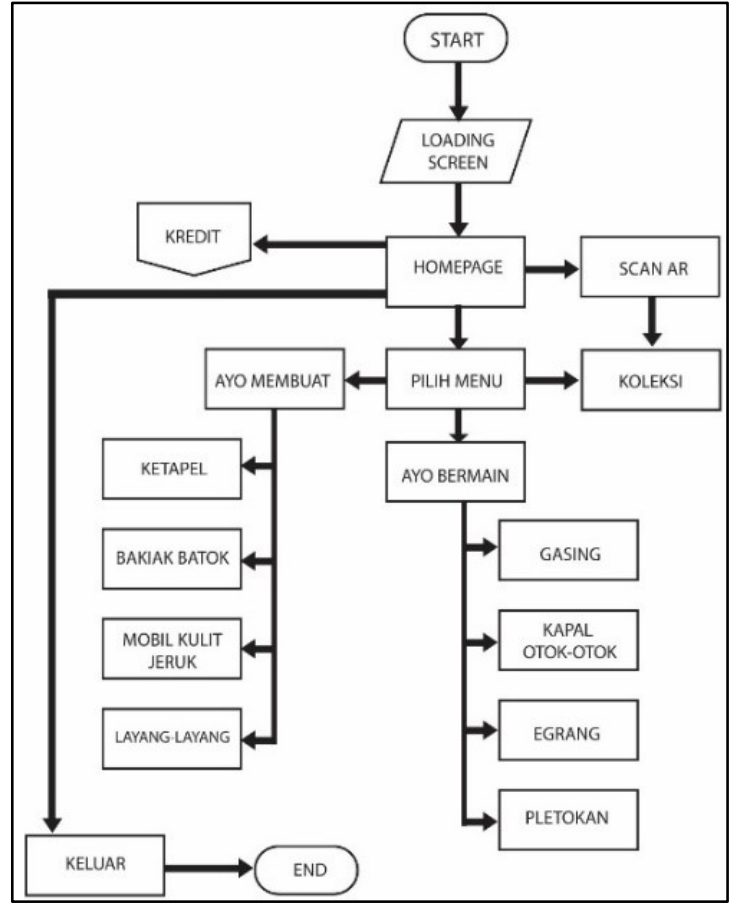

Fig. 8 Flowchart Keseluruhan Sistem Game

\section{B. Games Overview}

Ensiklo Dolanan is a game created with the concept of encyclopedia by presenting information along with illustrations of images and augmented reality to add insight as well as become a more interesting traditional game introduction media. In the game there are eight types of traditional games are divided into two types of game modes, namely making and playing. Make mode contains 4 games with different types of traditional games. The selection of traditional games is based on making steps that are considered easy to apply in children's play activities, with the aim that children can be interested in trying to make their own games. Gameplay in create mode is designed in the form of game puzzle with added instructions and gamemaking steps. 

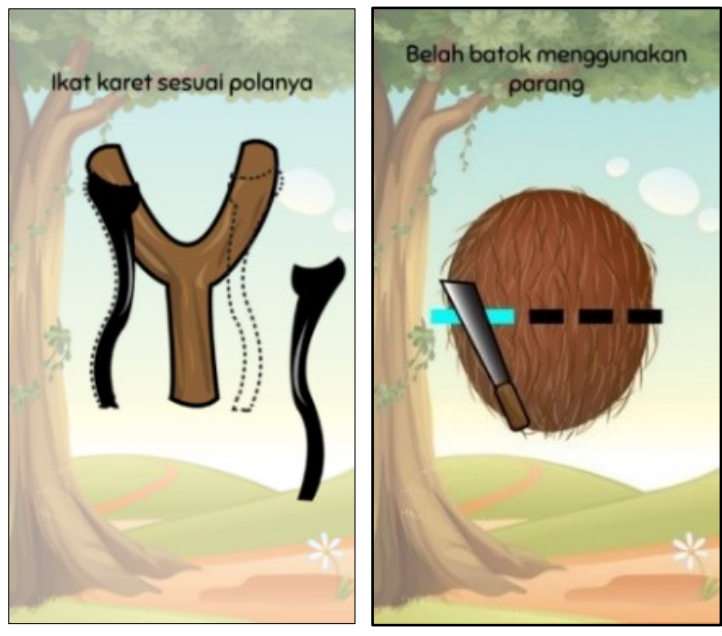

Fig. 9 Example menu view 'Ayo Membuat'

As for the mode of play, packed with arcade game form with different gameplay on each dolanan or game.
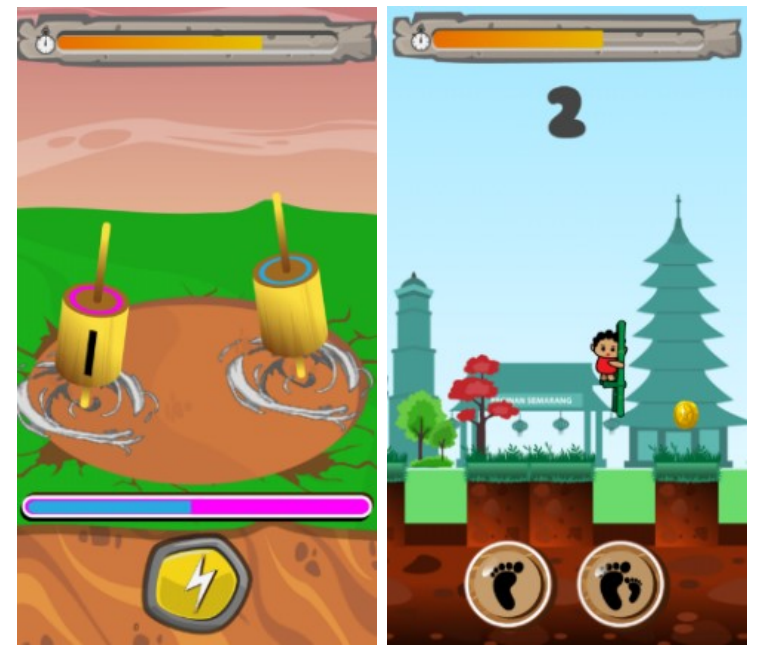

Fig. 10 Example menu view 'Ayo Bermain'

\section{Game Test Result}

After making the game, then the next test and the spread of post-test questionnaires to determine the assessment of the game and its influence in the efforts of preservation of traditional games. And obtained the following results:

\section{1) Game Ensiklo Dolanan has interesting theme.}

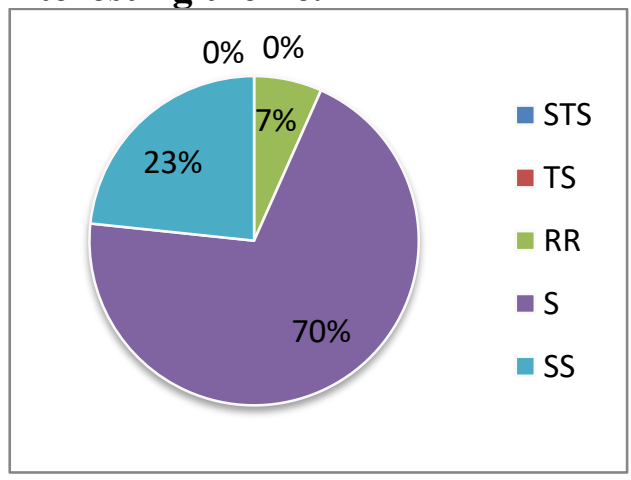

Fig. 11 Analysis diagram of the respondent's interest in game themes

Based on the diagram in Figure 11, $65 \%$ of respondents or 21 children agree that Game Ensiklo Dolanan has an interesting theme, $27 \%$ of respondents or 7 children stated strongly agree and $8 \%$ of respondents or 2 children say hesitate if the game has an interesting theme. Thus, a total of $92 \%$ of respondents agreed and strongly agree that Game Ensiklo Dolanan has an interesting theme.

2) Game Ensiklo Dolanan has an attractive display design.

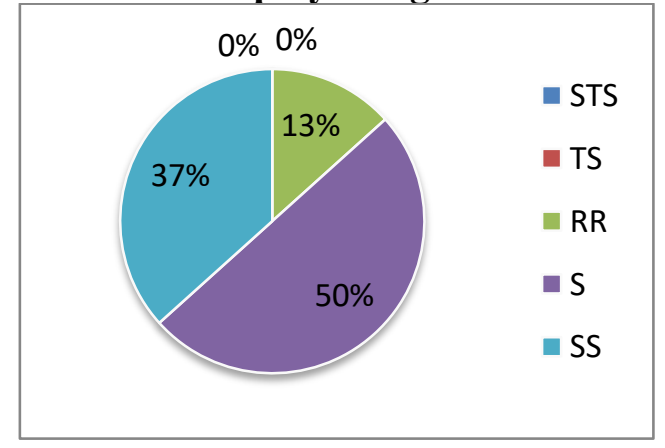

Fig. 12 Analysis diagram of the interest of respondents to the game display

From the analysis diagram in Figure 12 shows, as many as $50 \%$ of respondents or 15 children agreed and $37 \%$ of respondents or 11 children stated strongly agree that Game Ensiklo Dolanan has an attractive display design while $13 \%$ or 4 children expressed hesitancy on the 
grounds they are more interested game with 3 Dimension view.

\section{3) Game Ensiklo Dolanan easy to play}

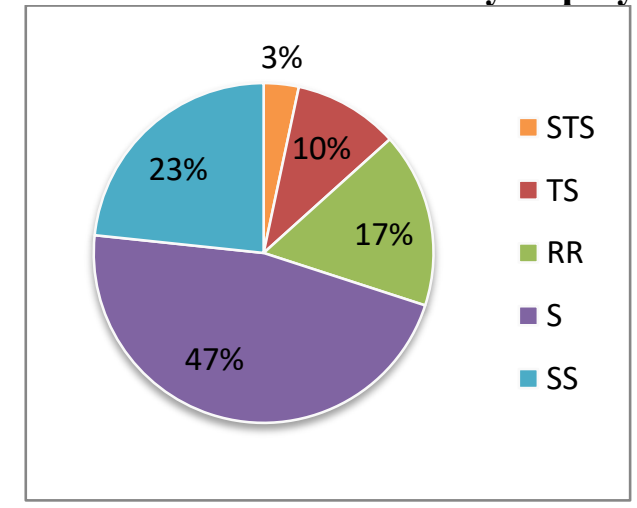

Fig. 13 Analysis diagram of the respondent's interest in gameplay

Based on the diagram in figure 13 obtained the results, $48 \%$ of respondents or 14 children agreed and $23 \%$ of respondents or 7 children stated strongly agree if Ensiklo Dolanan is easy to play. While $17 \%$ of respondents or 5 children expressed doubt, $10 \%$ of respondents or 3 children stated disagree and 3\% of respondents or 1 child stated strongly disagree if the game is easy to play because some of them less when playing games with gameplay that need reflex and concentration.

\section{4) Informasi \\ dalam}

tersampaikan dengan baik.

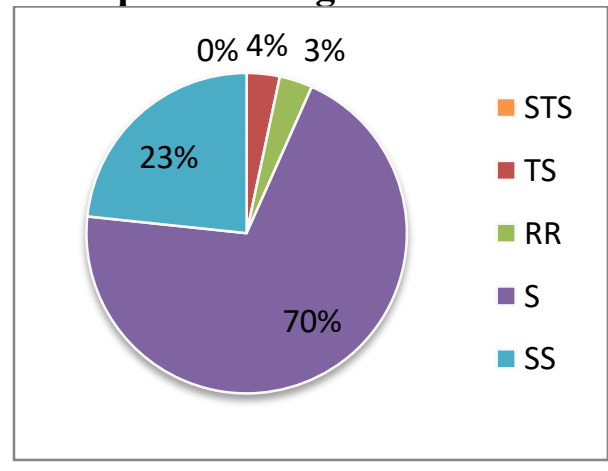

Fig. 14 Chart analysis of respondents' assessment of game information

Based on diagram analysis in figure $14,70 \%$ of respondents or 21 children agreed and $23 \%$ or 7 children stated strongly agree that the information in
Ensiklo Dolanan is well delivered. While $3 \%$ of respondents or 1 child expressed doubt and 3\% of respondents or 1 child said disagree, with reasons lazy to read information on the collection menu.

5) Game Ensiklo Dolanan can help preserve traditional games.

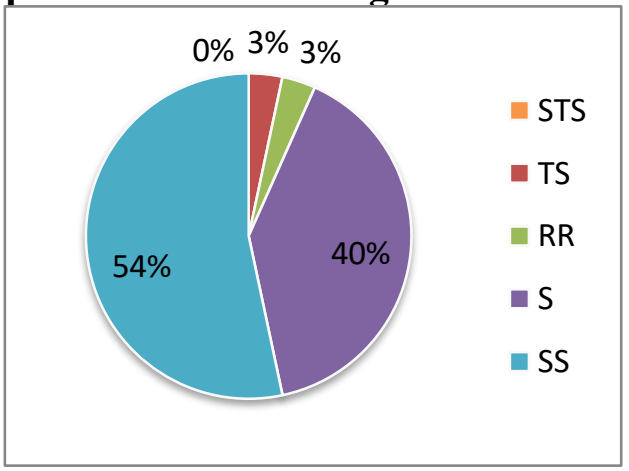

Fig. 15 Analysis diagram of respondents' opinions about the benefits of the game

From the diagram analysis in Figure 15 shows, $54 \%$ of respondents or 16 children stated strongly agree and $40 \%$ of respondents or 12 children agreed if Game Ensiklo Dolanan can help preserve the traditional game. Meanwhile, each $3 \%$ or 1 child expressed doubt and disagreed.

6) I became more acquainted with the traditional game.

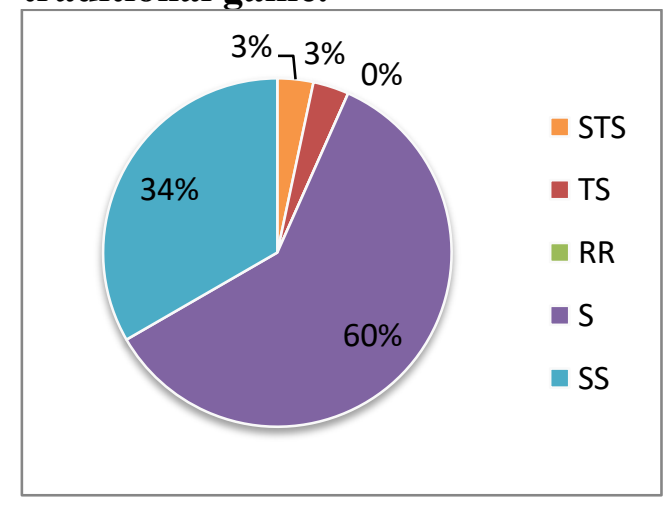

Fig. 16 Respondents' opinions about getting to know the traditional game

From the analysis diagram in Figure 16 shows, $60 \%$ of respondents or 18 children agreed and $34 \%$ of respondents or 10 children stated strongly agree that through this game they become more familiar with traditional games. While each 1 child 
or $3 \%$ of respondents stated disagree and strongly disagree.

7) I became interested in making a traditional game (dolanan) myself.

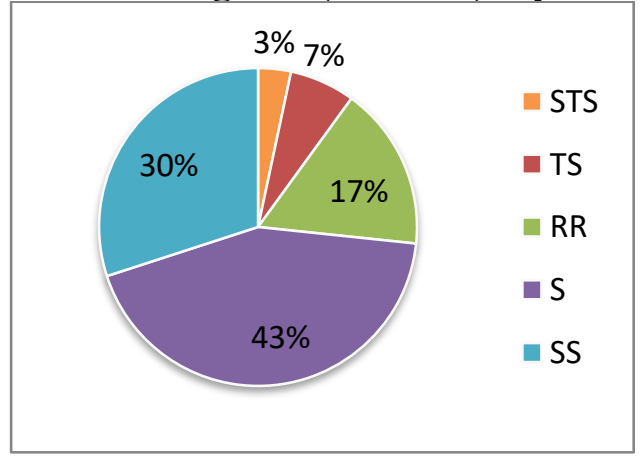

Fig. 17 Respondents' opinions about making traditional games

From the data in figure 17 obtained the results, $43 \%$ of respondents or 13 children agreed and $30 \%$ of respondents or 9 children stated strongly agree that they become interested in making their own traditional game. Meanwhile, $17 \%$ of respondents or 5 children expressed doubt, $7 \%$ of respondents or stated 2 children stated disagree and $3 \%$ of respondents or 1 child stated strongly disagree.

8) I became more interested in playing traditional games.

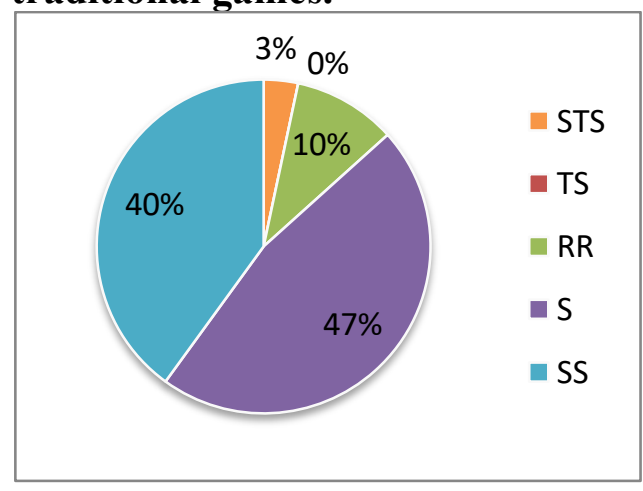

Fig. 18 Respondent's opinion about the interest of playing traditional games

Based on the diagram in Figure 18, $47 \%$ of respondents or 14 children agreed and $40 \%$ of respondents or 12 children stated strongly agree that they became more interested in playing traditional games. Meanwhile, $10 \%$ of respondents or 3 children expressed doubt and $3 \%$ or 1 child stated strongly disagree.

9) I am motivated to preserve the traditional game.

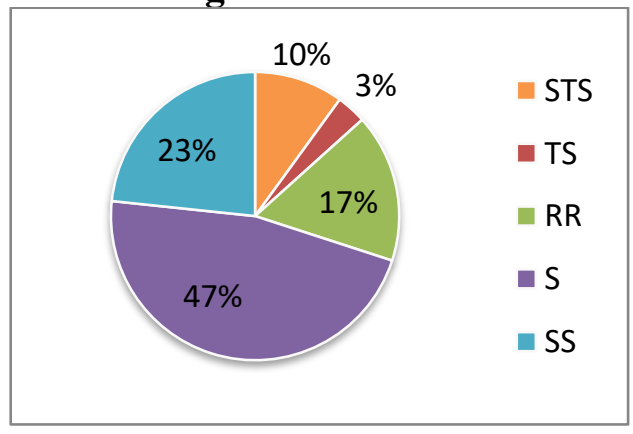

Fig. 19 Respondents' opinions about motivated traditional game play

Based on the diagram analysis in figure 19 , there are $47 \%$ or 14 children agreeing and $23 \%$ of respondents or 7 children stated strongly agree that they are motivated to preserve the traditional game. While $17 \%$ of respondents or 5 children expressed doubt, $10 \%$ of respondents or 3 children stated strongly disagree and $3 \%$ or 1 child stated disagree.

10) I'm more interested in playing traditional games than modern games.

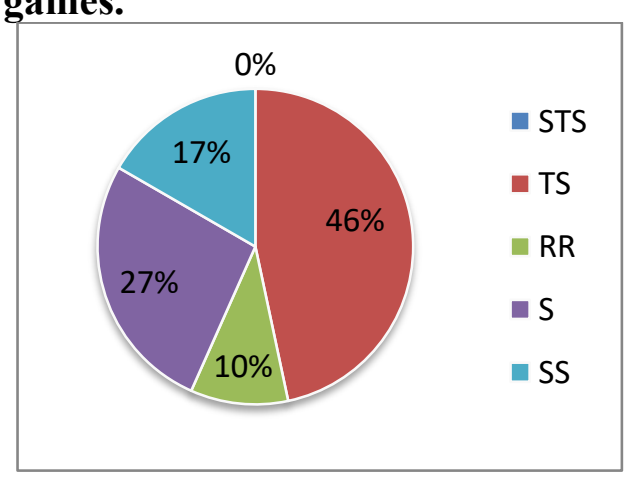

Fig. 20 Respondents' opinions about the interest between traditional games and modern games

Based on the data in Figure 20, the results obtained $30 \%$ of respondents or 8 children agreed and $19 \%$ or 5 children stated strongly agree that they are more interested in playing traditional games than modern games. Meanwhile, $46 \%$ of respondents that 
is 14 children stated disagree and $10 \%$ of respondents or 3 children expressed doubt.

Based on survey obtained results that Game Ensiklo Dolanan have an interest in terms of themes and design looks. In addition, the gameplay in this game is also easy to play. In terms of information delivery, most respondents agree and strongly agree if the in-game information has been well conveyed so as to make the children more familiar with traditional games.

While from other data shows Game Ensiklo Dolanan able to increase knowledge and insight of the children about the traditional game. In addition, this game managed to grow the interest of children to make their own traditional games and they also become increasingly interested in playing traditional games.

\section{CONCLUSION}

Ensiklo Dolanan created with the concept of educational games by presenting information and games around the traditional games are packaged in an interesting way to increase the child's enthusiasm in knowing the traditional game.

Based on the results of game testing can be concluded that Game Ensiklo Dolanan able to increase interest and knowledge of children against traditional games. Besides Game Ensiklo Dolanan also make children motivated to participate preserving the traditional game.

\section{ACKNOWLEDGE}

Elsa Regiana gratefully acknowledged to Beasiswa Unggulan scholarship support from Bereau for Planning and International Cooperation, Ministry of Education and Culture of Indonesia (Beasiswa Unggulan Kemendiknas Republik Indonesia).

\section{REFERENCES}

[1] M. S. Tedjasaputra, Bermain, mainan dan permainan. Grasindo, 2001.

[2] N. P. E. S. V. Winarthi Samurih Win (Bu), Mengenal sepintas seni budaya Bali. PT. Mitra Aksara Panaitan (Mapan), 2010.

[3] I. Khasanah, A. Prasetyo, and E. Rakhmawati, "Permainan tradisional sebagai media stimulasi aspek perkembangan anak usia dini," PAUDIA, vol. 1, no. 1, pp. 10-15, 2011.

[4] Suhendra, "Asa Permainan Tradisional Sebelum Punah," tirto.id, 2016. [Online]. Available: https://tirto.id/asa-permainantradisional-sebelum-punah-bx6W.

[Accessed: 29-Jan-2018].

[5] M. N. . Sitokdana, "Digitalisasi Kebudayaan Di Indonesia," Semin. Nas. Teknol. Inf. dan Komun. (SENTIKA 2015), vol. 2015, no. Sentika, pp. 99-108, 2015.

[6] R. Maulana, "Tingkat Perkembangan Pasar Game Mobile Indonesia Tiga Kali Lipat Amerika Serikat," id.techinasia.com, 2017. [Online]. Available:

id.techinasia.com/perkembanganpasar-game-indonesia-salah-satuyang-tertinggi-di-2016/amp/. [Accessed: 25-Oct-2017].

[7] "Main," KBBI Online, 2017. [Online]. Available: https://kbbi.web.id/main. [Accessed: 13-Oct-2017].

[8] Hamzuri and T. R. Siregar, Permainan Tradisional Indonesia. Direktorat Jenderal Kebudayaan, 1998.

[9] A. D. Karmadi, "Budaya lokal sebagai warisan budaya dan upaya pelestariannya," in Dialog Budaya Jawa Tengah: Ketahanan Budaya 
Lokal di Era Globalisasi, 2007, pp. 16.

[10] A. S. Mubah, "Strategi Meningkatkan Daya Tahan Budaya Lokal dalam Menghadapi Arus Globalisasi," vol. 24, pp. 302-308, 2011.

[11] D. H. Marbun, "Pemanfaatan Teknologi Sebagai Media Untuk Melestarikan Budaya Dan Nilai Luhur Bangsa Indonesia," Antrophos, vol. 1, pp. 1-7, 2013.

[12] "What is Digital Game," IGI Global. [Online]. Available: http://www.igiglobal.com/dictionary/digitalgame/7625. [Accessed: 10-Oct-2016].

[13] S. Hanrianto, "Pengaruh permainan tradisional gobag sodor terhadap peningkatan kemampuan penyesuaian sosial siswa kelas IV di Madrasah Ibtidhaiyah Yaspuri Kota Malang," Universitas Islam Negeri Maulana Malik Ibrahim, 2015.

[14] S. Setiawan, “'Studi Kepustakaan' Pengertian \& (Tujuan - Peranan Sumber - Strategi), gurupendidikan.co.id, 2017. [Online]. Available: gurupendidikan.co.id/StudKepustakaan-Pengertian-TujuanPeranan-Sumber-Strategi/. 